\title{
VEGETATIVE DEVELOPMENT AND GROWING DEGREE-DAYS OF TROPICAL AND WINTER FORAGES
}

\author{
Arthur C. Sanches ${ }^{1^{*}}$, Débora P. de Souza², Fernanda L. F. de Jesus ${ }^{3}$, Fernando C. Mendonça ${ }^{2}$, \\ Eder P. Gomes ${ }^{4}$
}

${ }^{1 *}$ Corresponding author. Universidade Federal da Grande Dourados/ Dourados - MS, Brasil.

E-mail: arthursanches@ufgd.edu.br | ORCID ID: https://orcid.org/0000-0003-2379-0634

\section{KEYWORDS \\ irrigation, Lolium \\ multiflorum, Avena \\ strigosa, base \\ temperature, grass.}

\begin{abstract}
One of the limitations to producing irrigated forages is setting suitable biometric parameters to establish the entrance of animals to grazing areas. Such parameters can be measured or even estimated. Estimates are advantageous for being practical and able to be used for grazing optimization. This study aimed to evaluate the correlation among growing degree-days (GDD), canopy height (CH), leaf area index (LAI), and number of cycle days (NCD) of Guinea grass (Panicum maximum cv. Mombaça) and Bermuda grass (Cynodon spp. Tifton 85) single cropped for one year and overseeded with black oat and ryegrass in the autumn-winter season. The study was carried out from February 2016 to February 2017, and forage crops were sprinkle irrigated. LAI and $\mathrm{CH}$ were measured twice a week, at intervals of 3 and 4 days. These parameters were correlated to GDD accumulation at each cutting cycle (CC). All the correlations showed high coefficients in linear fits. For spring-summer cycles, Guinea grass in exclusive cultivation showed the highest averages for $\mathrm{CH}$ and LAI, being $102.3 \mathrm{~cm}$ and 5.93, respectively. For autumnwinter cycles, when this grass was overseeded, it showed an LAI value similar to that when single cropped, which was of about 5.6. Yet single Bermuda grass presented lower values of LAI (one unit lower) and $\mathrm{CH}(16.4 \mathrm{~cm}$ lower) in the autumn-winter season when compared to that overseeded. The spring-summer cycles of Guinea grass had a duration of 24 days, after which no increase in leaf production was registered.
\end{abstract}

\section{INTRODUCTION}

At the end of the eighteenth century, beef and leather became important export products in Brazil. Three centuries later, the international scenario again becomes favorable to the Brazilian livestock sector with the entry of new consumers, namely Russia and China. The country has a large pasture area $\left(170 \mathrm{MM} \mathrm{ha}^{-1}\right)$ for cattle production (Moreira et al., 2014). It is believed that Brazilian productive potential can be further expanded by increasing the animal stocking rates, from the current population of 94 million of animal units (MAU) to a potential of 293 MAU (Strassburg et al., 2014).

Pasture growth is influenced by seasonal weather patterns, mainly solar radiation and temperature (Vogeler et al., 2016). In tropical countries such as Brazil, the high temperatures favor forage growth and, when properly managed, high yields have been achieved (Pezzopane et al., 2012; Gomes et al., 2015b; Andrade et al., 2016; Antoniel et al., 2016; Martuscello et al., 2016; Sanches et al., 2016).

Climatic indexes are widely used to estimate the growth of crops, such as plant length at different crop development stages (Andrade et al., 2016). One of the most popular climatic indexes is the growing degree-days (GDD), which is the sum of heat units when the mean daily temperatures are above the base temperature, below which plant metabolic processes start to cease or dramatically decrease (Moreno et al., 2014).

Among the plant traits known to indicate development, leaf area index (LAI) is also an important estimate; this index has been successfully used as a

\footnotetext{
${ }^{2}$ ESALQ-USP/ Piracicaba - SP, Brasil.

${ }^{3}$ Instituto Federal de Ciência e Tecnologia/ Araçuaí - MG, Brasil.

${ }^{4}$ Universidade Federal da Grande Dourados/ Dourados - MS, Brasil.

Received in: 8-21-2018

Accepted in: 2-8-2019
} 
parameter to set entrance and exit time of animals from pastures (Sousa et al., 2015). Szymczak et al. (2016) reported an increase in the LAI of Panicum maximum cv. Aries when a thermal sum of 696 GDDs was reached, and the onset of leaf senescence from 449 GDDs.

Given the above, understanding how the thermal sum acts on forage biometric parameters can help managing tropical and subtropical pastures. Thus, this study aimed to relate thermal sum (GDD) with the plant variables canopy height and leaf area index of two tropical forages (Panicum maximum cv. Mombasa and Cynodon spp.) both in exclusive cropping and overseeded with oats and ryegrass.

\section{MATERIAL AND METHODS}

The experiment was carried out between February 2016 and February 2017, in an experimental area of the ESALQ/USP campus, in Piracicaba-SP (Brazil) (22 $42^{\prime} 14^{\prime \prime}$ $\left.\mathrm{S}, 47^{\circ} 37^{\prime} 24^{\prime \prime} \mathrm{W}\right)$. The local soil is classified as eutroferric Red Nitosol (Santos et al., 2013), and its physical and chemical attributes are shown in Table 1.

TABLE 1. Soil chemical and grain size analyses from samples taken in the 0-20 and 20-40 cm layers. (Piracicaba City, Brazil, 2015).

\begin{tabular}{cccccccccccccc}
\hline Layer & $\mathrm{pH}$ & $\mathrm{P}$ & $\mathrm{K}$ & $\mathrm{Ca}$ & $\mathrm{Mg}$ & $\mathrm{H}+\mathrm{Al}$ & $\mathrm{Al}$ & $\mathrm{CEC}$ & Sand & Silt & $\mathrm{Clay}$ \\
\hline$(\mathrm{cm})$ & $\mathrm{CaCl}_{2}$ & $\mathrm{mg} \mathrm{dm}^{-3}$ & \multicolumn{1}{c}{$\mathrm{cmol}_{\mathrm{c}} \mathrm{dm}^{-3}$} & & $\mathrm{cmol}_{\mathrm{c}} \mathrm{dm}^{-3}$ & $(\%)$ & $(\%)$ & $(\%)$ \\
\hline $0-20$ & 5.3 & 72 & 0.9 & 3.9 & 1.8 & 3.1 & 0.2 & 9.74 & 35.7 & 19.2 & 45.1 \\
$20-40$ & 4.9 & 31 & 0.4 & 1.3 & 1.0 & 4.2 & 0.2 & 6.94 & 29.3 & 18.7 & 52.0 \\
\hline
\end{tabular}

$\mathrm{P}=$ phosphorus $\mathrm{K}=$ potassium $; \mathrm{Ca}=$ calcium; $\mathrm{Mg}=$ magnesium $; \mathrm{H}+\mathrm{Al}=$ potential acidity; $\mathrm{Al}=$ exchangeable aluminum; $\mathrm{CEC}=$ cation exchange complex.

Four 144- $\mathrm{m}^{2}$ experimental plots were set up in a total area of $576 \mathrm{~m}^{2}$. The experimental design was a randomized block with four treatments. Treatments were composed of two tropical forages both in exclusive cultivation and overseeded with oats and ryegrass. The species used here were grasses Bermuda grass (Cynodon spp. Tifton 85) and Guinea grass (Panicum maximum cv. Mombaça). The autumn-winter overseeding was carried out using winter forage species, namely oats (Avena strigosa Scherb, cv. Embrapa 29 - Garoa) and ryegrass (Lolium multiflorum cv. Fepagro São Gabriel).

The treatments were arranged as follows: (T1) Guinea grass in exclusive cultivation from $02 / 12 / 16$ to 02/13/17 over 12 regrowth cycles (RC); (T2) Guinea grass overseeded with black oats and ryegrass from $05 / 06 / 16$ to 09/22/16 over 4 RCs; (T3) Bermuda grass in exclusive cultivation from $02 / 19 / 16$ to $02 / 15 / 17$ over $14 \mathrm{RCs}$; (T4) Bermuda grass overseeded with black oats and ryegrass from $04 / 30 / 16$ to $10 / 14 / 16$ over 6 RCs. During the experiment, nitrogen fertilization was fractionated and applied after each cut cycle at rates of 80 and $50 \mathrm{~kg} \mathrm{~N}^{-1}$ cycle $^{-1}$ in spring-summer and autumn-winter seasons, respectively.

RCs were performed when the air temperature was not a limiting factor (early autumn, spring, and summer), on average every 21 and 28 days for Bermuda and Guinea grasses, respectively. In autumn-winter, they were carried out in accordance with black oats and ryegrass persistence in the field, which varied with the intercropped grass, Guinea (May to September) and Bermuda (April to October).

According to Köppen's classification, the local climate is a Cwa type, which stands for subtropical or tropical of altitude (Pereira et al., 2016). The lowest temperatures were registered during the second experimental quarter, with a thermal sum of $1694^{\circ} \mathrm{C}$ (Figure 1).

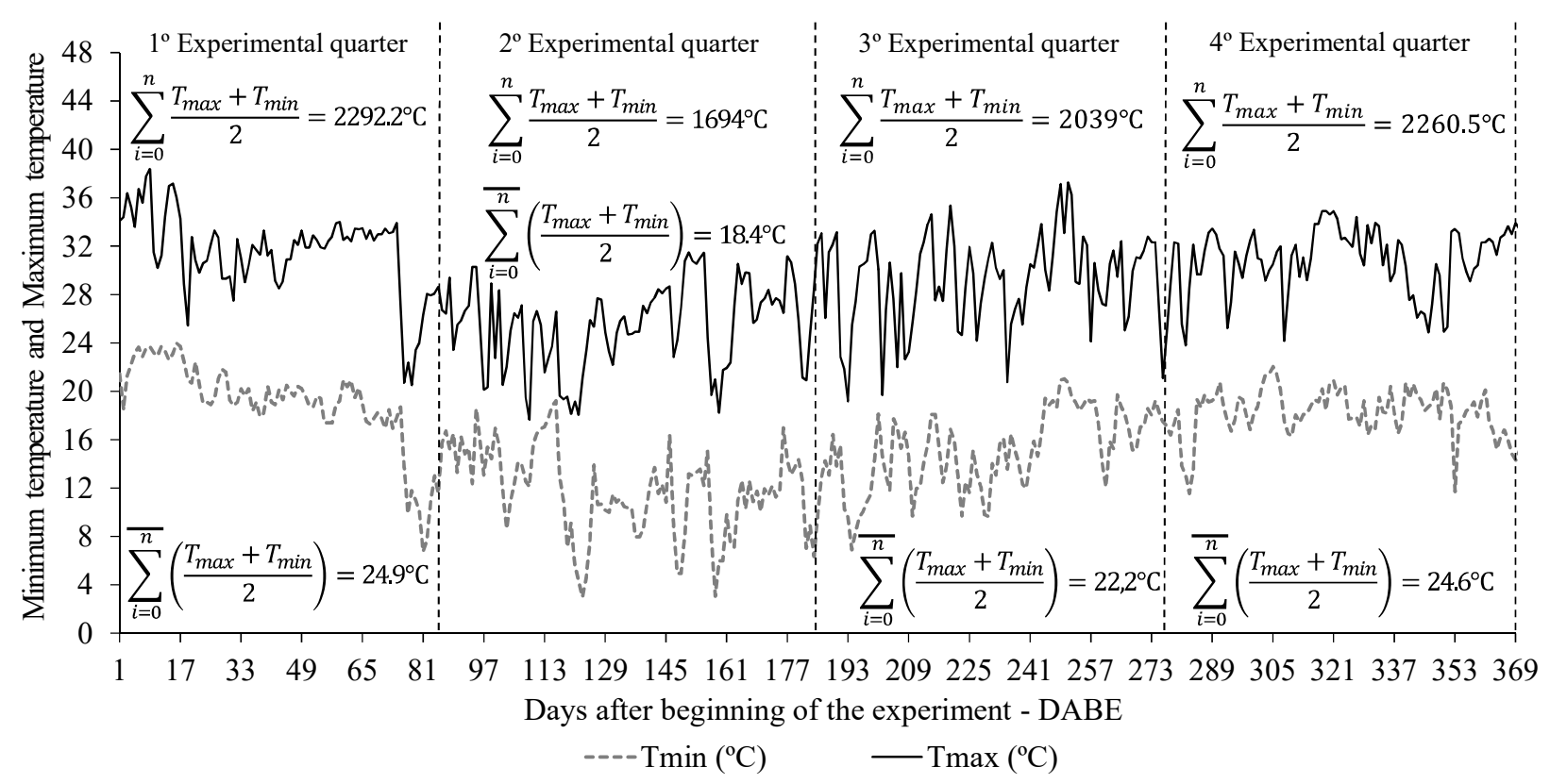

FIGURE 1. Minimum (Tmin) and maximum (Tmax) temperatures during the experimental period, from 02/2016 to 02/2017. Piracicaba-SP, Brazil. 
Plants were irrigated by a fixed and automated conventional sprinkler system with low-flow sectorial sprinklers (at a $90^{\circ}$ angle and individualized per plot). The service pressure was set at $25 \mathrm{mca}$ and flow rate at $0.592 \mathrm{~m}^{3}$ $\mathrm{h}^{-1}$, with emitters spaced $12 \times 12 \mathrm{~m}$ apart (sprinklers x plant rows), resulting in an application intensity (Ai) of $12.3 \mathrm{~mm}$ $\mathrm{h}^{-1}$. The irrigation time varied with crop water consumption measured by weighing lysimeters. The maximum interval between irrigations was previously established according to ETc estimates and soil water-storage capacity, in order to maintain the critical humidity of $70 \%$ available water capacity (AWC).

According to the literature, a post-cutting height of $0.3 \mathrm{~m}$ was left as residue for Guinea grass (Simonetti et al., 2016) and of $0.1 \mathrm{~m}$ for Bermuda grass (Sanches et al., 2017). In intercropping systems, cutting cycles varied depending on the winter forage growth. Each cycle duration was defined based on the following parameters light interception (LI, in \%); leaf area index (LAI, in $\mathrm{m}^{2} \mathrm{~m}^{-2}$ ), measured by an LAI 2000 Plant Canopy Analyzer (LI-COR ${ }^{\circledR}$ ); and canopy height $(\mathrm{CH}$, in $\mathrm{cm}$ ) (Sousa et al., 2015). Therefore, under exclusive cultivation, the cycles lasted 40 and 33 days after cutting (DAC) for Guinea and Bermuda grass, respectively.

When intercropped, a post-cutting height of $0.15 \mathrm{~m}$ was left as residue for both Guinea and Bermuda grasses. In these plots, the cutting and harvesting operations were repeated until black oats and ryegrass were fully removed. Whereas, in exclusive cultivation plots, cuts were performed for one year. Forage canopy height was measured at six random points within each plot from the soil to the curvature of the last fully expanded leaf.

Degree-day accumulation was estimated at various periods as a function of light interception, establishing a limit of LI $=95 \%$ for the cut. This way, during springsummer the cycles were 21 and 28 days for Bermuda and Guinea grass, respectively; while in autumn-winter, they were 33 and 40 days for Bermuda and Guinea grass, respectively. In intercropped systems, Bermuda and Guinea grasses were taken as reference for cycle determination. Growing degree-days (GDD) were calculated as proposed by Arnold (1959):

$$
\mathrm{GDD}=\frac{(\mathrm{TM}+\mathrm{Tm})}{2}-\mathrm{Tb}
$$

In which:

$\mathrm{TM}$ - Maximum daily temperature, in ${ }^{\circ} \mathrm{C}$;

$\mathrm{Tm}$ - Minimum daily temperature, in ${ }^{\circ} \mathrm{C}$,

$\mathrm{Tb}$ - Lower base temperature, in ${ }^{\circ} \mathrm{C}$.

In general, the lower base temperature (Bt) for tropical grasses ranges from 12 and $15^{\circ} \mathrm{C}$ (Silva et al, 2012; Moreno et al., 2014; Andrade et al., 2016) and for winter forages goes from 7 to $9^{\circ} \mathrm{C}$ (Oliveira et al., 2014). However, in intercropping systems no value is established; therefore, in these cases, the $\mathrm{Bt}$ was determined by the lowest standard deviation in degrees-days for more accurate data (Yang et al., 1995):

$$
B t=\frac{\sum_{i=1}^{n}(T i \cdot d i) \sum_{i=1}^{n} d i-n \sum_{i=1}^{n}\left(d i^{2}-T i\right)}{\left(\sum_{i=1}^{n} d i\right)^{2}-n \sum_{i=1}^{n} d i^{2}}
$$

In which:

$\mathrm{Bt}$ - lower base temperature, in ${ }^{\circ} \mathrm{C}$;

$\mathrm{Ti}$ - mean temperature of each specific season;

$\mathrm{n}$ - number of cutting cycles,

di - number of days required to reach a developmental stage in each cut or cycle.

Lower base temperatures for Guinea and Bermuda grass in exclusive cultivation were 14.8 and $14.1{ }^{\circ} \mathrm{C}$, respectively. When intercropped with black oats and ryegrass, these temperatures were 10.2 and $10.1{ }^{\circ} \mathrm{C}$, respectively. The results were processed using an MS Excel $^{\mathbb{Q}}$ spreadsheet.

In addition, we also performed statistical analysis of the LAI and $\mathrm{CH}$ data from both treatments (exclusive and overseeded cropping). This analysis followed the four (4) steps presented below:

1) Data separation by season (autumn-winter or spring-summer) for detection of differences in LAI and $\mathrm{CH}$ (cm) at each season individually. Afterwards, all the data of overseeded cropping (autumn-winter) was grouped to detect differences in LAI and $\mathrm{CH}$ between exclusive and overseeded cultivation.

2) The Anderson-Darling test was then applied to verify whether the data fitted to a normal distribution.

3) The F-test for variances was used to determine possible differences between exclusive and overseeded cropping treatments, so that we could choose adequate tests for the next step.

4) A two-sample t-test was applied to test for significant differences in LAI and $\mathrm{CH}$ data between both treatments (single cropping versus overseeded cropping). As mentioned above, the F-test for variances allowed us to choose between the $t$-test for equivalent variances and the $t$ test for different variances.

Finally, regression curves were fitted using a MS Excel ${ }^{\circledR}$ spreadsheet.

\section{RESULTS AND DISCUSSION}

The results from the Anderson-Darling test showed that all the data had a normal distribution; therefore, no data transformation was required.

When comparing autumn-winter and spring-summer seasons $(p=0.20)$, the $F$-test for variances showed differences in LAI $(p<0.05)$ for many treatments except for those using Guinea grass cv. 'Mombaça'. Moreover, the statistical tests allowed us to choose the t-test for equivalent or different variances. This test was used to make pairwise comparisons for both grass species ('Mombaça' and Cynodon spp.) and for both cropping systems (single and overseeded) when evaluating $\mathrm{CH}$. The test was also used for different variances of both 'Mombaça' and Cynodon spp., in almost all the periods in which LAI was involved.

The t-test for equivalent variances was applied to LAI data of 'Mombaça' exclusive cultivation in autumnwinter and in spring-summer $[\mathrm{P}(\mathrm{T}<=\mathrm{t})=0.44]$. It was also used for $\mathrm{CH}$ data for equivalent variances between: 'Mombaça' exclusive cultivation and overseeded in autumn-winter $[\mathrm{P}(\mathrm{T}<=\mathrm{t})=0.91]$, 'Mombaça' exclusive cultivation in autumn-winter and spring-summer $[\mathrm{P}(\mathrm{T}<=\mathrm{t})$ $=0.12]$, 'Cynodon' exclusive cultivation and overseeded in 
autumn-winter $[\mathrm{P}(\mathrm{T}<=\mathrm{t})=0.006]$, 'Cynodon' exclusive cultivation in autumn-winter and spring-summer $[\mathrm{P}(\mathrm{T}<=\mathrm{t})$ $=0.07]$.

For both grasses, the t-test for different variances was applied for comparisons of LAI data between exclusive and overseeded cultivations in autumn-winter ['Mombaça' grass: $\mathrm{P}(\mathrm{T}<=\mathrm{t})=0.62$; 'Cynodon' grass: $\mathrm{P}(\mathrm{T}<=\mathrm{t})=0.31$. The test was also used for different variances when comparing the data of 'Cynodon' grass LAI of autumnwinter and those of spring-summer $[\mathrm{P}(\mathrm{T}<=\mathrm{t})=0.04]$. All the results showed no significant differences.

The data were grouped in different periods according to plant growth physiology into autumn-winter (aut-win) and spring-summer (spr-sum). The annual thermal sum was slightly higher for Bermuda grass $\left(\mathrm{GDD}=3064^{\circ} \mathrm{C}\right)$ in relation to Guinea grass $\left(\mathrm{GDD}=2935.9^{\circ} \mathrm{C}\right)$, as it presents a Bt (basal temperature) lower than $0.7^{\circ} \mathrm{C}$. Figure 2 makes it clear the linear and increasing behavior of LAI and $\mathrm{CH}$ for Guinea grass in exclusive cultivation as a function of GDD and thermal sum, highlighting a direct relationship between this species growth and thermal sum (GDD). Likewise, while studying Mombaça grass (Panicum maximum cv. Mombaça) Melo et al. (2012) observed that variations in air temperature and light intensity promoted changes in leaf size and number, tiller density, and hence $\mathrm{LAI}$ and $\mathrm{CH}$ evolution.

The final LAIs for plants grown during the aut-win and spr-sum seasons were 5.6 and 5.9, Figure 2.a and Figure 2.b, respectively. Still, this difference reached 0.8 during the aut-win season (5.1) at 28 DAC. As seen in the study of Borges et al. (2011), the intercepted light flux has a linear and increasing relationship with LAI of Marandu grass and other forage species, varying with the season of the year.
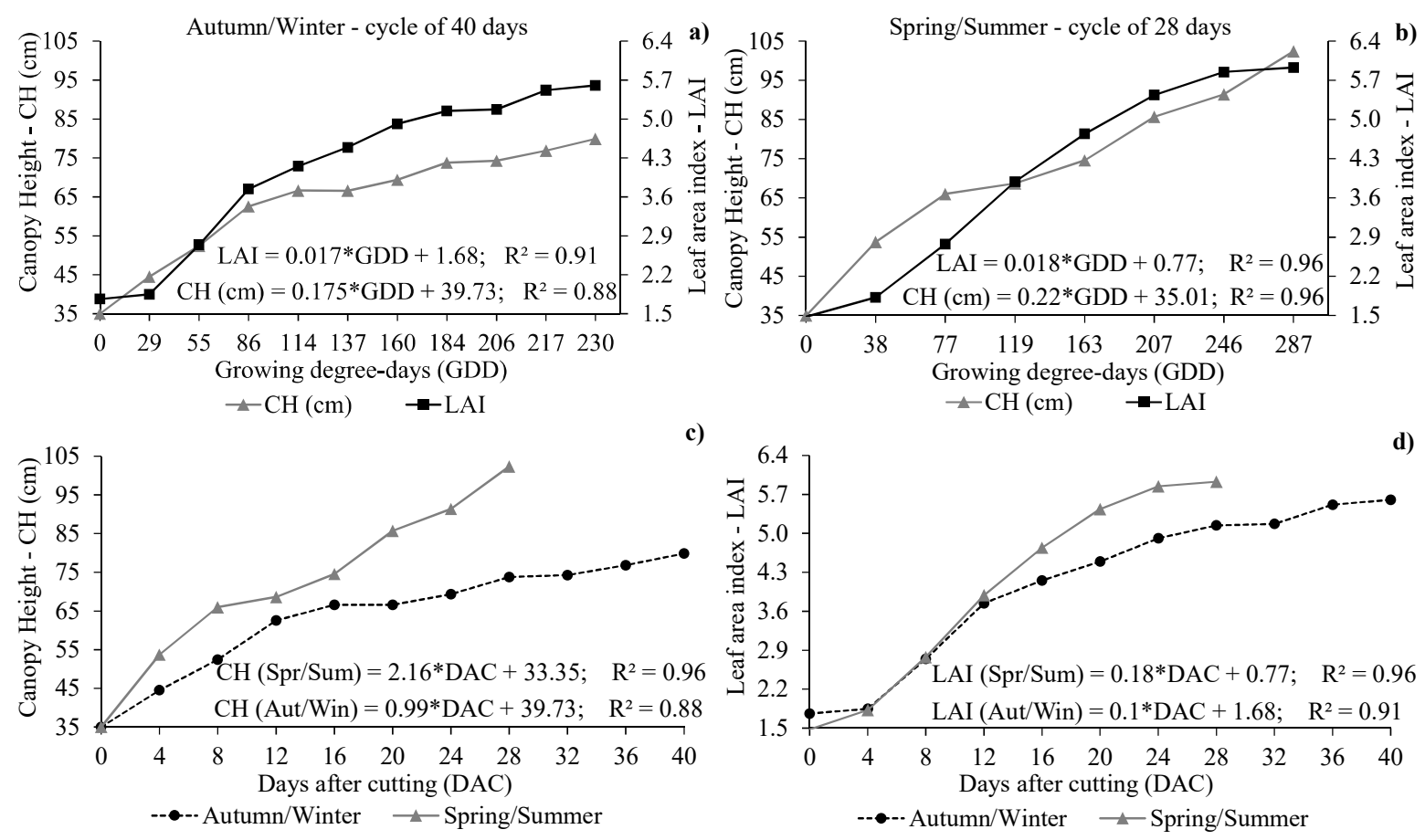

FIGURE 2. Guinea grass: empirical models for estimation of LAI and CH as a function of growing degree-days for the autumnwinter (a) spring-summer (b) seasons, and growth curves of CH (c) and LAI (d) as a function of the number of days after cutting. Piracicaba-SP, Brazil, 2016/17.

Despite having a continued growth, LAI of Guinea grasses stabilized in the spr-sum cropping at 24 DAC or a GDD of 245 GDD, as seen in Figure 2 (d) and (b), respectively. At this moment, the average LI exceeded 95\%, therefore indicated as a limit to the handling of animals as leaves stop growing and start senescing (Silva et al., 2015). The genus Panicum is well known for its wider leaves that may reach from 1.5 to $1.8 \mathrm{~m}$ in height; however, from a certain point in the cycle onwards, this growth occurs by stem elongation. In this study, this point occurred after 24 days, together with leaf senescence, similar to a study with
Aries grass that pointed to a leaf senescence onset after 449 GDD (Szymczak et al., 2016).

As shown in Figure 3 (b), Bermuda grass had a linear growth in the spr-sum cropping and showed similar values of final LAI for both seasons (3.27 and 3.26) with an average cycle of 21 and 33 days, respectively. The cycles adopted here fit well the growth and LAI of the studied forages, and the 12-day increase in aut-win cycles was coherent when compared to the spr-sum ones. This fact is justified by the accumulation in degrees-days that even with a higher mean cycle in aut-win, it was lower in 20 GDD when compared to spr-sum. 

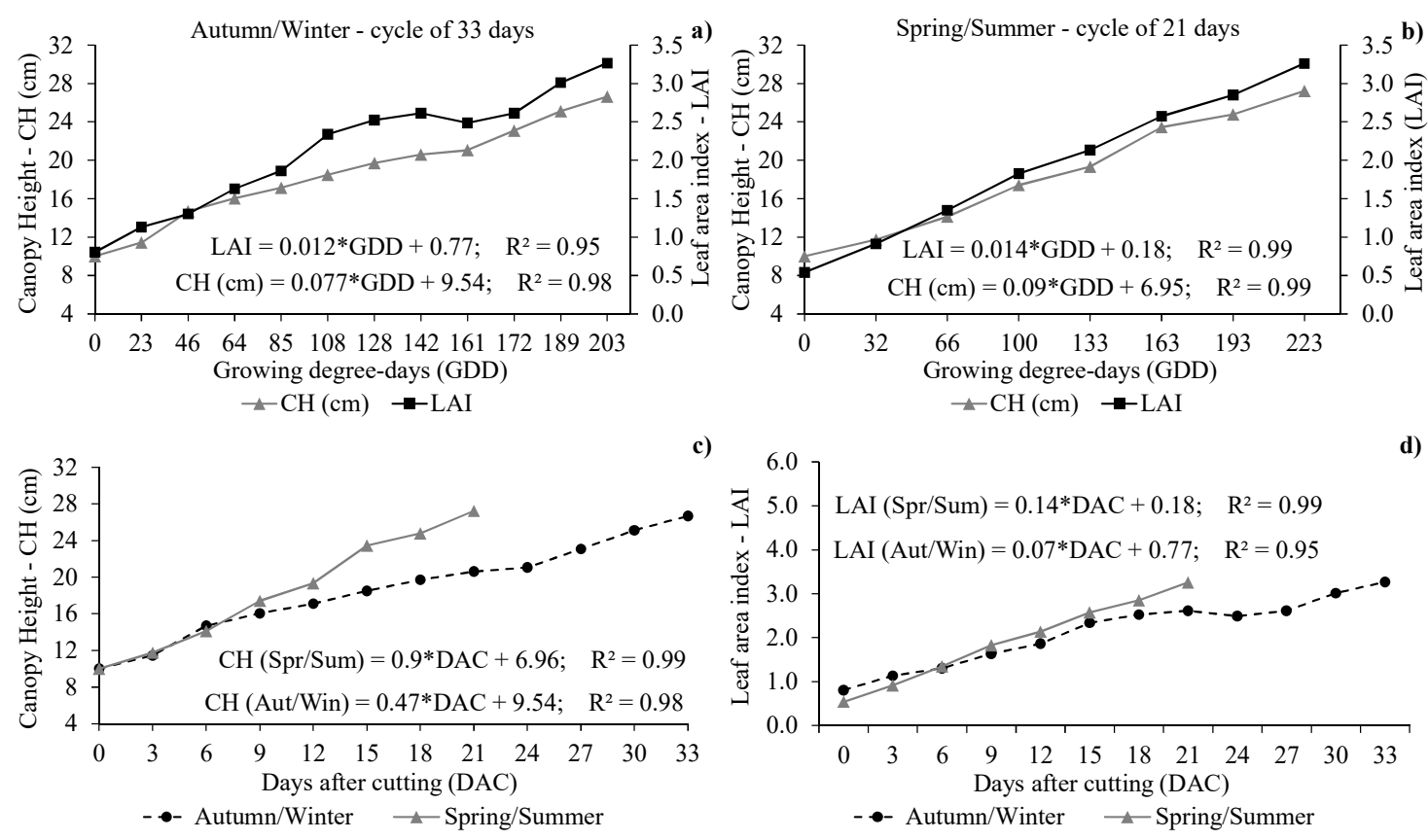

d)

FIGURE 3. Bermuda grass: empirical models for estimation of LAI and $\mathrm{CH}$ as a function of growing degree days for the autumnwinter (a) and spring-summer (b) seasons, and growth curves of CH (c) and LAI (d) as a function of the number of days after cutting. Piracicaba-SP, Brazil, 2016/17.

Overall, Bermuda grass showed LAI values lower than those of Guinea grass, which might be related to its shorter cycle. Another justification might be the high concentration of stems in stoloniferous grasses such as Bermuda grass, encompassing 35 to $45 \%$ of its total dry mass (Sanches et al., 2015, 2016).

The intercropping of Guinea grass with black oat and ryegrass during the aut-win season presented averages of final LAI and $\mathrm{CH}$ of 5.56 and $63.1 \mathrm{~cm}$, respectively (Figure 4). Given the smaller size of winter forages, Guinea grass was cut to a height of $15 \mathrm{~cm}$ (residue), reaching a final height about $17 \mathrm{~cm}$ smaller than that in exclusive cultivation during the aut-win period (Figure 2.a). By contrast, the LAI values were similar for both cropping systems; this was due to the presence of black oats and ryegrass that might have increased leaf mass. Ferrazza et al. (2013) studied different oat and ryegrass cultivars and observed a good response of them to the photoperiod during the aut-win season, with a good thermal sum and, hence, a greater number of tillers.
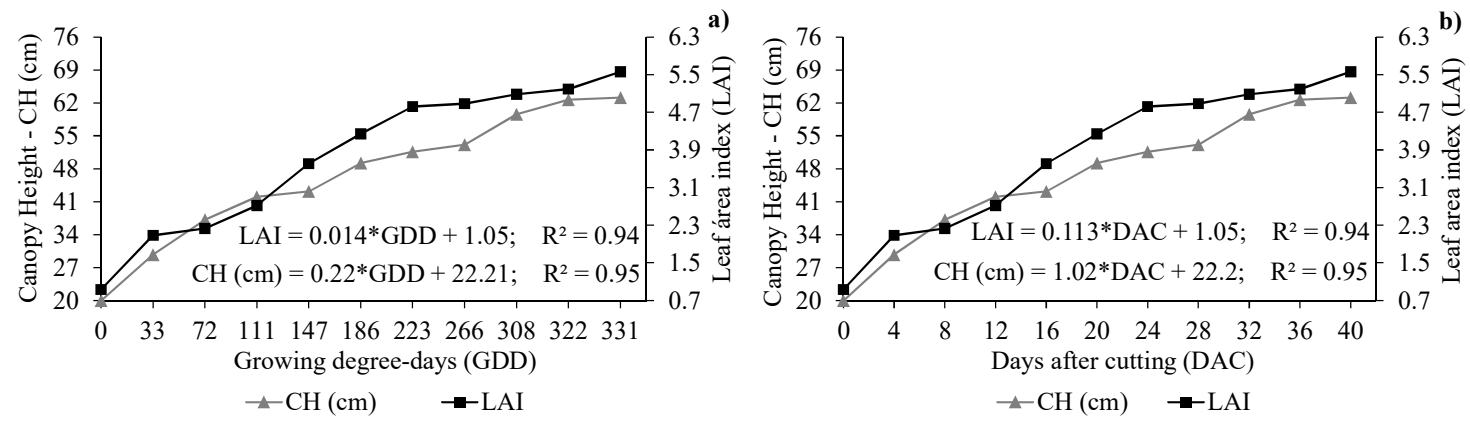

FIGURE 4. Guinea grass intercropped with oats and ryegrass: empirical models for estimation of LAI and CH as a function of growing degree-days (GDD) (a), and estimation of LAI and $\mathrm{CH}$ as a function of the number of days after cutting (DAC) (b). Piracicaba-SP, Brazil, 2016/17.

According to Oliveira et al. (2014), ryegrass has an average interval of 21 days between cuts, nearly 216 degrees-days. Presumably, the cutting point of oats should be close to that; thus, the growth rate of forage canopy peaked from the 28 days onwards, when Guinea grass might have started to stand out from winter forages, being about $12 \mathrm{~cm}$ longer at the final third. In addition, there was an increase in LAI of nearly 4.8 to 5.6 (Figure $4 . a$ and $4 . b$ ), which may have been due to a higher contribution of Guinea grass growth.
Furthermore, the intercropping of Guinea grass, black oats, and ryegrass showed no foliar gains and LAI increases, which could be attributed to the height left as a residue at post-harvest, decreasing Guinea grass growth because of the development of the winter forages. Some studies have highlighted the success of intercropping winter and small forages, such as those of the genus Cynodon spp. (Castagnara et al., 2012; Gomes et al., 2015a; Sanches et al., 2015), but few are the reports on the use of grasses of the genus Panicum. 
In the aut-win season, Bermuda grass reached the cutting point after a GDD of 1585.1 GDD, with mean $\mathrm{CH}$ and LAI of $43.1 \mathrm{~cm}$ and 4.29, respectively (Figure 5a). These values are higher than those found when this grass was grown alone in the aut-win. At the same time, a study by Sanches et al. (2015) with Cynodon spp. cv. Tifton 85 showed a 7\% higher accumulation of leaf dry mass. Probably the intercropping with oats and ryegrass contributes to accumulating leaves, what increases LAIs.

From the 30 days or a GDD of 277 GDD onwards, both $\mathrm{CH}$ and LAI began to show signs of stabilization (Figures 5.b). Unlike when grown alone, intercropped grasses probably started having a mass net gain at the end of its cycle from the day 30 because of the rapid responses of oats and ryegrass in shortening the cycle.
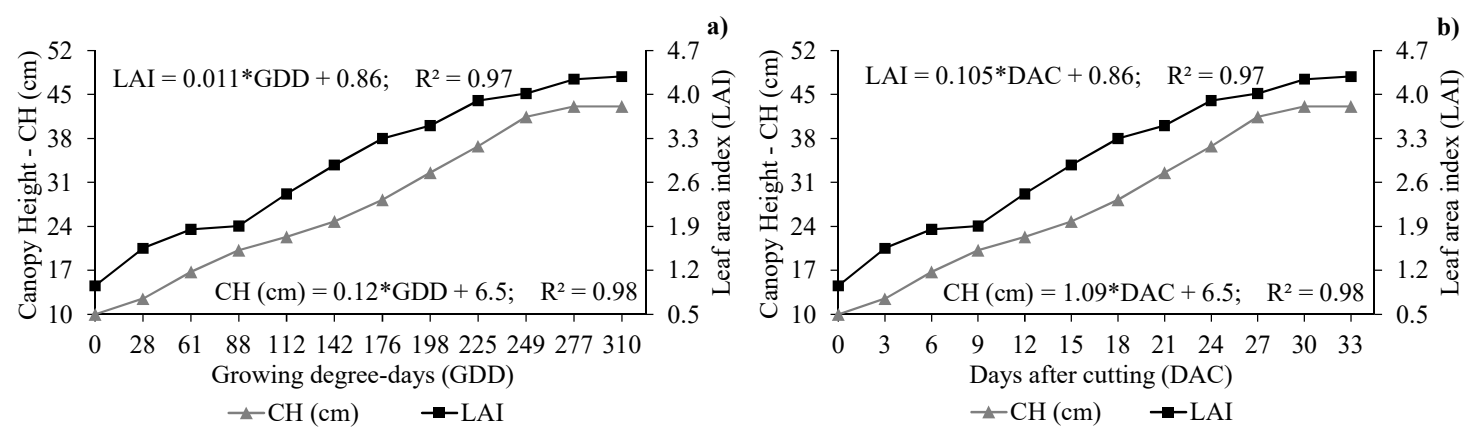

FIGURE 5. Bermuda grass intercropped with oats and ryegrass: empirical models for estimation of LAI and CH growing degreedays (GDD) (a), and LAI and $\mathrm{CH}$ as a function of the number of days after cutting (DAC) (b). Piracicaba-SP, Brazil, $2016 / 17$.

\section{CONCLUSIONS}

The correlations found in this study among canopy height $(\mathrm{CH})$, leaf area index (LAI), and growing degreedays (GDD) enabled the development of empirical models, with applicable linear regression adjustments and high coefficients of correlation for all treatments. Both LAI and $\mathrm{CH}$ are good parameters when managing the entering of animals to pastures of Guinea and Bermuda grasses, both in exclusive or overseeded cropping systems. The thermal sum (GDD) can be used as an aid in defining the moment of entry of animals to pastures as well.

For Guinea grass, spring-summer forage accumulation cycle lasted 24 days, or 246 growing degreedays (GDD), as no significant leaf contribution was observed from this point onwards. Yet Bermuda grass presented great differences between exclusive and overseeded cropping, where oats and ryegrass contributed to an increase in forage canopy accumulation with the same GDD.

\section{ACKNOWLEDGEMENTS}

To the Foundation for Research Support of the state of São Paulo (FAPESP) for the aid granted to the regular research project $n^{\circ} 2012$ / 23002-6.

\section{REFERENCES}

Andrade AS, Santos PM, Pezzopane JRM, Araújo LC, Pedreira BC, Pedreira CGS, Lara MAS (2016) Simulating tropical forage growth and biomass accumulation: an overview of model development and application. Grass and forage science 71(1):54-65. DOI:

https://doi.org/10.1111/gfs.12177

Antoniel LS, Prado GD, Tinos AC, Beltrame GA, De Almeida JV, Cuco GP (2016) Pasture production under different irrigation depths. Revista Brasileira de Engenharia Agrícola e Ambiental 20(6):539-544. DOI: http://dx.doi.org/10.1590/1807-

1929/agriambi.v20n6p539-544
Arnold CY (1959) The determination and significance of the base temperature in a linear heat unit system. American Society for Horticultural Science 74:430-445.

Borges BMMN, Silva Júnior LC da, Teixeira Lucas F, Silva WJ da (2011) Relação entre o fluxo luminoso interceptado em diferentes épocas no índice de área foliar de diferentes forrageiras. Semina: Ciências Agrárias 32(4):1589-1594. DOI: https://doi.org/10.5433/16790359.2011v32n4p1589

Castagnara DD, Neres MA, Oliveira PSRD, Jobim CC, Três TT, Mesquita EE, Zambom MA (2012) Use of a conditioning unit at the haymaking of Tifton 85 overseeded with Avena sativa or Lolium multiflorum. Revista Brasileira de Zootecnia 41(6):1353-1359. http://dx.doi.org/10.1590/S1516-35982012000600006

Ferrazza JM, Soares AB, Martin TN, Assmann AL, NicolaV (2013) Produção de forrageiras anuais de inverno em diferentes épocas de semeadura. Revista Ciência Agronômica 44(2):379-389. Available:

https://search.proquest.com/openview/2ba714612593a65a $01 \mathrm{f} 64580 \mathrm{ec} 185008 / 1$ ?pq-origsite $=\mathrm{gscholar} \& \mathrm{cbl}=2028909$.

Gomes EP, Rickli ME, Cecato U, Farhate CVV, Goes RHDT, Oliveira ED (2015a) Productivity of Tifton 85 grass irrigated and overseeded with winter forages. Acta Scientiarum Animal Sciences 37(2):123-128. DOI: http://dx.doi.org/10.4025/actascianimsci.v37i2.25512

Gomes EP, Rickli ME, Cecato U, Vieira CV, Sapia JG, Sanches AC (2015b) Produtividade de capim Tifton 85 sob irrigação e doses de nitrogênio. Revista Brasileira de Engenharia Agricola e Ambiental-Agriambi 19(4):317323. DOI: http://dx.doi.org/10.1590/18071929/agriambi.v19n4p317-323

Martuscello JA, Majerowicz N, Da Cunha DNFV, De Amorim PL, Braz TGS (2016) Características produtivas e fisiológicas de capim-elefante submetido à adubação nitrogenada. Archivos de zootecnia 65(252):565-570. Available: http://www.redalyc.org/html/495/49549091014/ 
Melo JC, Dos Santos PM, Dos Santos AC, Alexandrino E, De Paula Neto JJ (2012) Respostas morfofisiológicas do capim Mombaça submetido a doses de resíduo líquido de laticínios. Revista de Ciências Agrárias/Amazonian Journal of Agricultural and Environmental Sciences 54(3):247-258. DOI:

http://dx.doi.org/10.4322/rca.2012.020

Moreira CD, Pereira DH, Coimbra RA, Moreira DA (2014) Germinação de gramíneas forrageiras em função da inoculação de bactérias diazotróficas. Scientific Electronic Archives 6:90-96.

Moreno LS, Pedreira CG, Boote KJ, Alves RR (2014) Base temperature determination of tropical Panicum spp. grasses and its effects on degree-day-based models. Agricultural and Forest Meteorology 186:26-33. DOI: https://doi.org/10.1016/j.agrformet.2013.09.013

Oliveira LV, Ferreira, OGL, Coelho RAT, Farias PP, Silveira RF (2014) Características produtivas e morfofisiológicas de cultivares de azevém. Pesquisa Agropecuária Tropical 44(2):191-197. Available: http://www.redalyc.org/html/2530/253031354011/

Pereira FFS, Dal Pai E, Montenegro RJV, Román RMS, González AMGO, Escobedo JF (2016) Estudo comparativo da evapotranspiração de referência entre localidades no estado de São Paulo e na província de Habana. IRRIGA 21(2):395-408. DOI: http://dx.doi.org/10.15809/irriga.2016v21n2p395-408

Pezzopane JRM, Santos PM, Mendonça FC, Araújo LCD, Cruz PGD (2012) Dry matter production of Tanzania grass as a function of agrometeorological variables. Pesquisa Agropecuária Brasileira 47(4):471-477. DOI: http://dx.doi.org/10.1590/S0100-204X2012000400001

Sanches AC, Gomes EP, Rickli ME, Fasolin JP, Soares MR, De Goes RH (2015) Produtividade e valor nutritivo do capim Tifton 85 irrigado e sobressemeado com aveia. Revista Brasileira de Engenharia Agricola e Ambiental-Agriambi 19(2):126-133. DOI: http://dx.doi.org/10.1590/18071929/agriambi.v19n2p126-133

Sanches AC, Gomes EP, Rickli ME, Friske E (2016) Produtividade, composição botânica e valor nutricional do Tifton 85 nas diferentes estações do ano sob irrigação. IRRIGA 1(1):221-232. DOI: http://dx.doi.org/10.15809/irriga.2016v1n1p221-232

Sanches AC, Gomes EP, Rickli ME, Friske E, Fasolin JP (2017) Productivity and nutritive value of Tifton 85 in summer, with and without irrigation under different Nitrogen doses. Engenharia Agrícola 37(2):246-256. DOI: http://dx.doi.org/10.1590/1809-4430-eng.agric.v37n2p246$256 / 2017$
Santos HG, Jacomine PKT, Anjos LHC, Oliveira VA, Oliveira JB, Coelho MR, Lumbreras JF, Cunha TJF (2013) Sistema brasileiro de classificação de solos. Rio de Janeiro, Centro Nacional de Pesquisa de Solos.

Silva EAD, Silva WJD, Barreto AC, Oliveira Junior, ABD, Paes JMV, Ruas JRM, Queiroz DS (2012) Dry matter yield, thermal sum and base temperatures in irrigated tropical forage plants. Revista Brasileira de Zootecnia 41(3):574-582. DOI: http://dx.doi.org/10.1590/S1516-35982012000300014

Silva SC, Sbrissia AF, Pereira LET (2015) Ecophysiology of C4 forage grasses-Understanding plant growth for optimising their use and management. Agriculture 5(3) 598625. DOI: http://dx.doi.org/10.3390/agriculture5030598

Simonetti A, Marques WM, Costa LVC (2016) Grass productivity (Panicum maximum), with different doses of biofertilizer. Revista Brasileira de Engenharia de Biossistemas 10(1):107-115. DOI: http://dx.doi.org/10.18011/bioeng2016v10n1p107-115

Sousa LF, Santos JGD, Alexandrino E, Mauricio RM, Martins AD, Sousa JTL (2015) Método prático e eficiente para estimar a área foliar de gramíneas forrageiras tropicais. Archivos de zootecnia 64(245):83-85. Available: http://www.redalyc.org/pdf/495/49538689014.pdf

Strassburg BB, Latawiec AE, Barioni LG, Nobre CA, Da Silva VP, Valentim JF, Assad, ED (2014) When enough should be enough: Improving the use of current agricultural lands could meet production demands and spare natural habitats in Brazil. Global Environmental Change 28:84-97. DOI:

https://doi.org/10.1016/j.gloenvcha.2014.06.001

Szymczak LS, Schuster MZ, Lustosa SB, Lang CR, Moraes A (2016) Habilidade competitiva de capim aries com plantas daninhas no estabelecimento: características morfológicas. Revista Ciência Agronômica 47(3):471-480. Available:

http://www.redalyc.org/html/1953/195345160007/

Vogeler I, Mackay A, Vibart R, Rendel J, Beautrais J, Dennis S (2016) Effect of inter-annual variability in pasture growth and irrigation response on farm productivity and profitability based on biophysical and farm systems modelling. Science of the Total Environment 565:564-575. DOI:

https://doi.org/10.1016/j.scitotenv.2016.05.006

Yang S, Logan J, Coffey DL (1995) Mathematical formulae for calculating the base temperature for growing degree-days. Agricultural and Forest Meteorology 74(12):61-74. DOI: https://doi.org/10.1016/01681923(94)02185-M 